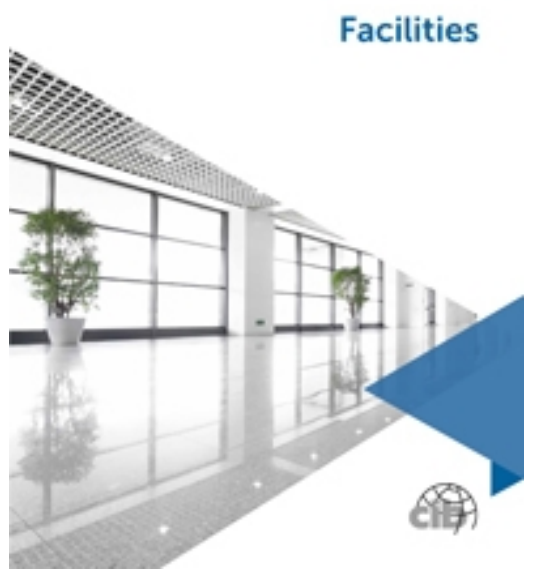

\title{
AN INVESTIGATION INTO THE ERRONEOUS ACCESS AND EGRESS BEHAVIOURS OF BUILDING USERS AND THEIR IMPACT UPON BUILDING PERFORMANCE
}

\begin{tabular}{|r|l|}
\hline Journal: & Facilities \\
\hline Manuscript ID & f-05-2019-0053.R2 \\
\hline Manuscript Type: & Original Article \\
\hline Keywords: & $\begin{array}{l}\text { building environmental performance, Energy Efficiency, User behaviour, } \\
\text { Access, Egress, Case study }\end{array}$ \\
\hline
\end{tabular}

\section{SCHOLARONE ${ }^{m}$ Manuscripts}


Ref: Manuscript ID f-05-2019-0053.R1

Journal: Facilities

Title: An investigation into the erroneous access and egress behaviours of building users and their impact upon building performance

\section{REVIEWERS' COMMENTS AND AUTHORS' RESPONSE}

The authors wish to extend thanks to the referees for their constructive comments and suggestions. The paper reads much improved as a result of addressing this positive feedback.

Each individual comment has either been addressed or defended as appropriate (refer below) and a final file resubmitted for your consideration using the 'tracked changes' feature within MS Word. Once again, thank you.

\begin{tabular}{|c|c|c|}
\hline No. & Referees' Comments & Author's Response \\
\hline & \multicolumn{2}{|l|}{ Editor's Comments } \\
\hline \multirow[t]{2}{*}{1} & $\begin{array}{l}\text { The reviewer(s) have recommended } \\
\text { publication, but also suggest } \\
\text { making some minor revisions to } \\
\text { your manuscript before it gets } \\
\text { published. Therefore, I invite you to } \\
\text { respond to the reviewer(s)' } \\
\text { comments and revise your } \\
\text { manuscript. }\end{array}$ & $\begin{array}{l}\text { Thank you for this very positive outcome, we are } \\
\text { delighted to read this response and have made every } \\
\text { effort to review and revise the paper as appropriate. }\end{array}$ \\
\hline & \multicolumn{2}{|l|}{ Review No. 1 Comments } \\
\hline 2 & $\begin{array}{l}\text { The paper takes a very narrow } \\
\text { scope on egress. But the reality is } \\
\text { that it is only one part of the design } \\
\text { consideration for a building. }\end{array}$ & $\begin{array}{l}\text { Thank you for your observation here. } \\
\text { We do agree that the work is narrowly defined and } \\
\text { this decision was deliberate - we ideally wanted to } \\
\text { secure greater depth and penetration of the work vis- } \\
\text { à-vis conduct a more broader and all-encompassing } \\
\text { study that may have only excoriated the surface of a } \\
\text { wider problem superficially. } \\
\text { So we contend that the narrow definition is a strength } \\
\text { of this work and have attempted to address this } \\
\text { within the paper [refer below]. }\end{array}$ \\
\hline 3 & $\begin{array}{l}\text { A good design should reduce } \\
\text { energy use or not rely on } \\
\text { mechanical means } \\
\text { heating/cooling. These aspect needs } \\
\text { to be explored further in the paper. }\end{array}$ & $\begin{array}{l}\text { We do completely concur with this observation/ } \\
\text { recommendation and indeed feel that a holistic } \\
\text { solution to building energy consumption and } \\
\text { consequential environmental pollution is required. } \\
\text { However, the extant literature contains an abundance } \\
\text { of articles on reducing fossil energy usage and/or the } \\
\text { transition to greener fuels - but our research has } \\
\text { focused on the area that has received least academic } \\
\text { attention - namely, mechanical operation of access } \\
\text { and egress routes and user behaviour. }\end{array}$ \\
\hline 4 & $\begin{array}{l}\text { Some level/s of engagement with } \\
\text { the building users are clearly } \\
\text { required beyond the expectation of }\end{array}$ & $\begin{array}{l}\text { We do concur with this observation (regards other } \\
\text { approaches) and such as an oversight on our behalf. } \\
\text { Consequently new text has been added to the }\end{array}$ \\
\hline
\end{tabular}




\begin{tabular}{|c|c|c|}
\hline & $\begin{array}{l}\text { what the design will assist with. } \\
\text { What about using other approaches } \\
\text { to inform students and staff? For } \\
\text { example, Green Impact is about } \\
\text { student behaviour on campus } \\
\text { supporting reducing, energy, water } \\
\text { and other resource uses. } \\
\text { What about feedback to the } \\
\text { architect or changing briefs to } \\
\text { include these issues so they can be } \\
\text { mitigated in the future for other } \\
\text { such buildings and in university } \\
\text { campuses. } \\
\text { University of Lincoln has been } \\
\text { specifically mentioned as the place } \\
\text { where the building manager } \\
\text { previously worked...should this be } \\
\text { revealed in the paper? }\end{array}$ & $\begin{array}{l}\text { theoretical sub-section viz: } \\
\text { "In particular, building users must be better } \\
\text { educated about how their behaviour can reduce their } \\
\text { (and the building's) environmental impact. Various } \\
\text { pragmatic options and techniques are available to } \\
\text { engender proactive environmental behaviour such as } \\
\text { creating a psychological sense of ownership or } \\
\text { reinforcing good habit formation (c.f. White et al., } \\
\text { 2019). It is most likely that a coalescence of these } \\
\text { techniques will derive the optimum result." } \\
\text { We also fully concur that feedback to architects and } \\
\text { future client is key and have added new text to the } \\
\text { practical implications section viz: } \\
\text { "At this juncture, both the architect and client should } \\
\text { work closer together to ensure that the future design } \\
\text { of a building is fit for purpose and can accommodate } \\
\text { the anticipated influx of building users at peak times } \\
\text { without compromising the building's energy } \\
\text { performance. However, herein resides an important } \\
\text { conundrum that requires some further } \\
\text { consideration." } \\
\text { And also... } \\
\text { "Perhaps this is where a more robust post occupancy } \\
\text { evaluation (cf. Roberts et al., 2020) would provide } \\
\text { primary data (and hard evidence) to support the } \\
\text { refinement of future designs created by an architect } \\
\text { in the client's brief but also ensure a soft landing (cf. } \\
\text { Pärn et al., 2017)." } \\
\text { We also fully agree that reference to University of } \\
\text { Lincoln should be removed and have now referred } \\
\text { instead to a higher education institute. }\end{array}$ \\
\hline 5 & $\begin{array}{l}\text { As indicated, the paper takes a very } \\
\text { narrow scope and leaves it as a } \\
\text { narrow scope without really } \\
\text { exploring or placing the research } \\
\text { into the wider context. In this } \\
\text { respect, the paper falls short. }\end{array}$ & $\begin{array}{l}\text { We believe that we have given a suitable defence to } \\
\text { this comment in item no. } 2 \text { above. }\end{array}$ \\
\hline 6 & $\begin{array}{l}\text { The paper needs a good edit. Some } \\
\text { figures on the plan or an elevation } \\
\text { sketch would greatly assist with } \\
\text { understanding and communicating } \\
\text { better the direction of traffic during } \\
\text { the peak periods described. }\end{array}$ & $\begin{array}{l}\text { The authors have reviewed and edited the paper once } \\
\text { more and have made various minor edits and changes } \\
\text { throughout. } \\
\text { However, we do not see a valid reason to include a } \\
\text { plan or elevation view of a rotating door that only } \\
\text { does just that - in a bi-directional manner. We do not }\end{array}$ \\
\hline
\end{tabular}




\begin{tabular}{|c|c|c|}
\hline & & $\begin{array}{l}\text { feel that such would augment the quality of value of } \\
\text { the paper. }\end{array}$ \\
\hline & \multicolumn{2}{|l|}{ Review No. 2 Comments } \\
\hline 7 & $\begin{array}{l}\text { Theoretical and practical } \\
\text { considerations and imlpications, } \\
\text { with their discussions and } \\
\text { contributions, should be discussed } \\
\text { in separate topics. }\end{array}$ & $\begin{array}{l}\text { Thank you for this constructive comment. As } \\
\text { suggested, both sections have now been split into } \\
\text { two. }\end{array}$ \\
\hline
\end{tabular}




\title{
AN INVESTIGATION INTO THE ERRONEOUS ACCESS AND EGRESS BEHAVIOURS OF BUILDING USERS AND THEIR IMPACT UPON BUILDING PERFORMANCE
}

\begin{abstract}
Purpose: This study investigates the behaviour of building users and how this behaviour impacts upon building energy performance. Specifically, the work examines the behavioural traits of able-bodied users of a large higher education building who erroneously access and egress the building using doorways intended for disabled users only.

Research Approach: An inductive methodological approach is adopted that employs grounded theory to devise new insights into building users' access and egress habits. Structured interviews are conducted to collect primary data from 68 building users of a large educational building over a four-week period. Responses to questions posed provide the basis for a tabularisation of behavioural traits.

Findings: Reasons for able-bodied building users' preferences to using disabled access are identified and discussed; these are thematically grouped under the headings of: apathy, convenience, emergency, ergonomics, ignorance and phobia. Building upon these findings, the research then offers insights into the approaches that could be adopted to change the erroneous behaviours. These approaches include: education of building users on the impact their behaviour has upon building performance and environmental pollution; more stringent regulation to penalise repeat offenders; and changes to building entrance design using obtrusive (i.e. radio frequency identification tags) and unobstrusive control measures (i.e. a second entrance doorway or slower opening mechanism).

Originality: This study is the first of its kind to investigate the rationale for able-bodied building users erroneously utilising disabled persons' access and egress doorways within a building, which as a consequence, inadvertently reduces the building's environmental performance.
\end{abstract}

\section{KEYWORDS}

Building environmental performance, energy efficiency, user behaviour, access, egress. 


\section{INTRODUCTION}

Buildings and infrastructure within the built environment are responsible for consuming approximately $40 \%$ of the world's energy resources (EPBD, 2010). As a consequence of this mass consumption, the built environment contributes significantly towards pollution (Omer, 2008); environmental degradation (Li et al., 2013); and greenhouse gas emissions (Zhang et al., 2018). In 2010, buildings accounted for $32 \%$ of total global final energy use thus contributing 19\% of energy-related greenhouse gas emissions (Lucon et al., 2015). Left unabated, this energy consumption will lead to: global climatic change (Moran et al., 2017); energy price increases (Rogelj et al., 2013); energy shortages (Wang et al., 2012); and social inequalitiesy and injustices (Jenkins et al., 2018). Within the higher education sector, university buildings contribute to these energy consumption figures despite efforts to improve the performance of such buildings (Wang et al., 2013).

Besides the establishment of energy policies, rating schemes and standards around the world ( $\mathrm{Lu}$ and Lai, 2019), efforts are being made to reduce energy consumption using, for example: intelligent building management systems to optimise heating, ventilation and air conditioning (HVAC) (Goetzler et al., 2014); automatic lighting systems linked via sensor-based networks (de Bakker et al., 2017); and alternative energy sources such as photovoltaics (Su et al., 2012), wind energy (Bitar et al., 2012) or biomass (Rosillo Callé, 2007). However, an important consideration that has not received adequate attention is the behaviour of building users even within today's 'smart buildings' (Lawrence et al., 2016). User behaviour vastly influences the amount of energy expended by a building (Stern et al., 2016). Steemers et al. (2009) proffer that behavioural factors account for a $30 \%$ variance in the energy usage required to heat a building, and a 50\% variance in the energy usage needed to cool a building. Understanding and changing user behaviour can therefore lead to energy consumption reductions of between 10-24\% (Langevin et al., 2013). Within the prevailing academic discourse on changing user behaviour, scant research has been conducted to investigate why able-bodied building users insist on using 'power assisted' disabled user access and egress doorways. Such behaviour engenders fluctuations in the internal temperatures of buildings and increased usage of energy to compensate for such (either via heating or cooling the building's internal environment). A significant part of the problem is that disabled access and egress doorways are specifically designed to open slowly thus, unduly exposing the internal environment to external climatic conditions and internal heat loss or gain. 
Given this contextual backdrop, this research aims to investigate building users' behaviour and how it can affect energy performance. Specifically, the work will examine the impact of able-bodied users as they erroneously access and egress a building envelope using disabled user doorways. Concomitant objectives of this work are: to determine factors that influence the behaviour of able-bodied users when they use disabled access and egress doorways and how such could be discouraged; to engender environmental impact by saving energy and reducing occupant wastage, thereby reducing a building's carbon footprint and running costs; and to influence the future design of buildings to better accommodate user behaviour that impacts upon environmental performance.

\section{RESEARCH APPROACH}

An inductive research methodological approach (Woo et al., 2017) was adopted that employed grounded theory (Ivey, 2017) to devise new theories about building users' access and egress habits. Specifically, the research sought to identify and explain the behavioural reasons underpinning the usage of disabled persons' access doorways by able-bodied building occupants and users. Inductive research is widely used within extant literature and has been successfully used to, for example: assess the sustainability of construction practices (Goel et al., 2019); validate observational research (Bostic et al., 2019); conduct a critical review of extant literature using bibliometrics (Roberts et al., 2019); and develop a conceptual framework from case study research (Al-Saeed et al., 2019). This extensive body of knowledge demonstrates that an inductive research approach is an appropriate strategy for this research.

From an operational (vis-à-vis epistemological) perspective, a two-phase program of research was implemented. In phase one, and prior to conducting field research, an interpretivist qualitative analysis (Cobo et al., 2018) of extant literature was conducted using the bibliometric analysis software VOS Viewer (cf. Chamberlain et al., 2019). In this instance, each item of the published literature constituted was the a unit of analysis for this secondary data (Martins et al., 2018). VOS viewer was employed to put together visual bibliometric networks, in groupings classified by researcher, location of research and topic. The Web of Science database was used as the preferred database because it provides a comprehensive range of pertinent scientific publications produced by a range of credible publishers (Mongeon and Paul-Hus, 2016). Moreover, web of science has been used extensively within 
past studies because it has: excellent coverage of high impact and influential journals (Giménez-Espert and Prado-Gascó, 2019); and includes journals in pertinent subject areas of humanities, social science and engineering (Al-Saeed et al., 2020). Only academic journals were reviewed, as conference contributions were considered to be of lower quality and standing (cf. Hosseini et al., 2019). Keywords used for the search were: building environmental performance, energy efficiency, user behaviour, access, egress and educational setting.

In phase two, a case study was conducted on a large multi-storey educational building located in the UK's second city Birmingham (refer to Figure 1a and 1b). Case study research has been extensively tried and tested within prevailing construction and civil engineering management research. For example: Owusu-Manu et al. (2016) measured fairness in construction cost consultancy pricing services in Ghana; Edwards and Love (2016) studied construction plant and machinery maintenance protocols and procedures within the UK utilities sector; and Fisher et al. (2018) assessed the performance of building design for people with dementia. The building, valued at $£ 46$ million, is split into two blocks - block one being five storeys high and block two being six storeys high. Primary quantitative data on energy consumption (in kW.h), collected over a circa 12 month period ( $1^{\text {st }}$ March 2017 to $24^{\text {th }}$ February 2018) at 30 minute intervals throughout each 24 hour day (refer to Figure 2), revealed that although building functionality and usage did not change significantly, the overall time series trend exposed two important observations regarding: i) daily fluctuations which occur as a result of building usage and are seen to ebb and flow as the building experiences an influx and outflux of students and staff throughout the 24 hour period; ii) annual trend - which, perhaps more importantly, appears to be increasing and although a singular year is not conclusive evidence of a clear trend, it has prompted investigation into determining this apparent trend and-what measures can be undertaken to reduce energy consumption levels. The answer to this broad question is complex and will require numerous additional studies and perspectives to be considered which are beyond the scope of a single research paper - hence, this present study applied-focuses to and investigatedupon the singular aspect of building user behaviour. In this regard, primary qualitative data (cf. Stanek et al., 2016) was collected by speaking to building users who accessed the building using the disabled access and egress doorways and recording their reasons for this choice. These building users were also asked whether they would use these doorways again if they knew 
that it caused heat loss wastage, and if there were any ways by which people could be prevented from using the doors unnecessarily. To record participant responses, an informal, semi-structured questionnaire was utilised as the main data collection instrument (Dawson et al., 2013). The building was monitored by two researchers for a one-hour period, four times a day between $8-9 \mathrm{am}, 12-1 \mathrm{pm}, 4-5 \mathrm{pm}$ and $8-9 \mathrm{pm}$ over a four week period commencing in January 2018.

$<$ Insert Figure 1a, $1 \mathrm{~b}$ and 2 about here $>$

A qualitative analysis was undertaken of data collected using bibliometric analysis to provide explanation of the findings and provide opportunities to develop new theories. A tabulated taxonomy was then constructed using codification of the narratives obtained from participants to illustrate the main reasons for the use of disabled access and egress routes by able-bodied people. To validate the results, the findings were presented to the building's Carbon and Energy Reduction Manager (CERM) to garner feedback and suggestions for further improvements in building design and functionality that could influence user behaviour and future architectural design.

\section{A SYNTHESIS OF LITERATURE ON THE IMPACT OF USER BEHAVIOUR ON BUILDING PERFORMANCE}

Using VOSViewer, a database of 1,489 publications was assembled. This body of knowledge illustrates that research published on the effect of user behaviour on commercial and domestic buildings can be split into four thematic groups, namely: i) environmental considerations which cause a user to behave in a certain way that impacts upon energy usage; ii) measurement of the effectiveness of strategies in reducing energy usage; iii) prediction of future occupant behaviour; and v) the influence of providing information to occupants about how they can reduce energy use. Within this body of knowledge, the most common keywords identified in the titles and abstracts of the papers were: control, temperature, window, saving, framework, practice, home, dwelling, uncertainty, summer, schedule, light, appliance, intervention, construction and algorithm (refer to Figure 3). There were 134 clusters in total, indicating that a wide range of topics have been researched in the area.

$<$ Insert Figure 3 about here $>$ 
From the qualitative analysis undertaken, there appears to be a marked difference in the articles published during the earlier and later periods within 1978 to 2018. Between 1978 and 2004, there were just ten papers written, the first three of which were by Socolow (1978), Seligman et al. (1978) and Sonderegger et al. (1978) respectively. This early research highlights the impact of occupant behaviour on energy performance of residential buildings. For example, Sonderegger et al. (1978) establish that about $33 \%$ of the variation in gas consumption of 205 identical townhouses can be caused by occupant-related consumption patterns, rather than the design of the house. Between 2004 and 2018 there was a steady increase in the amount of papers published; this could be due (amongst other reasons) to the increasing use of green energy which has been backed by popular public opinion.

To gain greater insight, bibliometric maps were also constructed for: prominent journals in the field; research output by country; and research published by institution. The bibliometric map constructed for the key journals publishing pertinent materials within this subject area revealed that Energy and Buildings (impact factor (IF): 4.067) is the journal most frequently publishing relevant studies (refer to Figure 4), followed by Building Research and Information. In terms of geographical distribution of the research output, the USA leads with 331 published papers, followed by England with 185 published papers and China with 158 papers (refer to Figure 5). Regards publishing institution, Tsinghua University has published the highest number of publications with 54, followed by Polytechnic University of Turin with 41 (refer to Figure 6).

$<$ Insert Figures 4, 5 and 6 about here $>$

In educational settings, behavioural factors have been calculated to account for a $30 \%$ variance in the energy usage required to heat a building, and a 50\% variance in the energy usage required to cool a building (Steemers et al., 2009). With user behaviour directly influencing the amount of energy consumed, it is possible therefore to reduce energy consumption through understanding user behaviour and applying strategies to change this. Langevin et al. (2013) indicate that changing behaviour can furnish a 10-24\% energy saving. If every building lowered their energy usage by this amount then the amount of $\mathrm{CO}_{2}$ released into the atmosphere per day would reduce dramatically. 
Interestingly, there is no clear definition for the term 'occupant behaviour', with all researchers interpreting the term in a slightly different way. Some consider the energyconsuming activities of people when they are inside the buildings (Sunikka-Blank and Galvin, 2012; Allan, 2010). Other studies include investment as a behaviour, for example, whether to purchase and install solar panels for housing is viewed as part of occupant behaviour (Allcott and Mullainathan, 2010). The International Energy Agency (IEA) attempts to define energy-related occupant behaviour as:

“...observable actions or reactions of a person in response to external or internal stimuli, or respectively actions or reactions of a person to adapt to ambient environmental conditions such as temperatures, indoor air quality and sunlight" (Polinder et al., 2013).

However, most studies and definitions appear to include common thematic clusters of research in and around the areas of: energy wastage; open windows; lighting management; occupant control over thermal comfort; and building design.

\section{Energy Wastage}

Masoso and Grobler (2010) study occupant behaviour and examine the quantity of energy wasted during non-occupied hours of commercial buildings in Botswana and South Africa. They find that more energy is used during non-working hours $(56 \%)$ than during working hours (44\%), partly as a result of occupants leaving lights and equipment on at the end of the day, and partly due to poor zoning and controls. Other literature by Ouyang and Hokao (2009) investigates the energy-saving potential of occupants as a result of educating them in order to prompt a change in their behaviour. This study (ibid), carried out in China, splits 124 households into two dichotomous groups, where one group is advised to behave as normal, and the other group is taught new habits with the aim of making them more environmentally conscious. By a comparison of the energy usage of both groups at exactly one year apart, it is revealed that effective promotion of energy-conscious behaviour could lower household electricity consumption by more than $10 \%$ (ibid). Eco-feedback is also shown as an effective way to influence behaviour and gamification is similarly identified as an effective way of instigating behavioural change (Paone and Bacer, 2018).

\section{Open Windows}


Voluminous literature has studied user behaviour in buildings in terms of opening windows. Cali et al. (2016) examine window opening behaviour in German households, while Jian et al. (2011) observe window gap behaviour in five flats in Beijing, China. Fabi et al. (2016) state that this area has been heavily researched due to the impact of opening windows, whereby a large amount of energy is required to sustain the indoor environment. Wang and Greenberg (2015) assess varied management methods on window gap behaviours in the visualisation within the EnergyPlus simulation software package. They (ibid) discover the numerous roles of window gap behaviour in occupants' indoor comfort and conclude that the HVAC system might accomplish energy savings of up to $47 \%$ with mixed-mode ventilation for summers.

\section{Lighting Management}

Managing lighting in a building is another specific behaviour that has received attention from a number of researchers (Heydarian et al., 2016). Bourgeois et al. (2006) investigate the total energy effect of manual and automated lighting control, based on a sub-hourly occupancybased control model. Behaviour involving lights in offices has been researched by a number of researchers (Yun et al., 2012a; Zhou et al., 2015). Studies illustrate that the outdoor level of natural brightness and occupant behaviour are the two most influential factors upon the amount of energy use in a building - lighting behaviour of occupants is in turn influenced by occupancy, time of day and occupant movements within the building (Yun et al., 2012b, Galasiu and Atif, 2002).

\section{Occupant Control over Thermal Comfort}

A study of offices in China observes how an occupant sets comfort criterion by operating lights, office equipment, space thermostats and HVAC systems (Hong and Lin, 2012). The observed occupant behaviour can be split into three types: i) austerity - whereby occupants are proactive in saving energy; ii) standard - the activity of average occupants; and iii) wasteful - where occupants do not care about energy usage (ibid). The simulation results demonstrate that the impact of occupant behaviour on building energy use is significant. It is calculated that an office composed of austerity style employees would consume up to $50 \%$ less energy than that composed of standard employees, while wasteful employees would consume up to $90 \%$ more energy than standard employees. The warming and cooling of an environment is also a predominant area of research. Heating and cooling buildings uses up to 
$73 \%$ of the total energy used by a building (Zhou et al., 2015). For commercial buildings this requires an average of $40 \%$ of all energy used, and for a residential building, $30 \%$ of the total energy needed for the building (Lucon et al., 2014). Research by Majcen et al. (2015) illustrates how occupant behaviour uses varying amounts of energy in terms of changing the heating settings, by producing a model showing theoretical and actual heating consumption of households in the Netherlands. The research identifies that significant factors affect heating behaviour, including: occupants' perception of temperature; humidity of the air; occupancy level; time; thermostat setting; ventilation system; and heating type.

\section{Building Design}

The design of a building has a huge effect on its energy usage (An et al., 2017). The design of every building in the UK must adhere to regulations set out in The Equality Act, Part M (access to and use of buildings) (The Building Regulation, 2010a) and Part L (conservation of fuel and power) (The Building Regulation, 2010b) of the Building Regulations and the British Standard BS 8300-2 2018 design of an accessible and inclusive built environment (BSI, 2018). These regulations and legislations will have influenced the design details of the building to be examined in this case study, and so will impact upon issues regarding its energy wastage. The Equality Act administers the requirement to make reasonable adjustments to a building, ensuring a disabled person is not discriminated against, and replaces the almost identical requirement within the Disability Discrimination Act. A disabled person should have adequate accessibility while entering a building and lift access should be provided, according to the Equality Act, 2010.

Part M of the Building Regulations states that "reasonable provision" should be made for people to access and use a building and its facilities, including any extensions made to that building. Approved Documents in Part M of the Building Regulations, whilst not legally binding, provide practical guidance on how the requirements of the Building Regulations could be satisfied. They suggest that for moving between floors, the most ideal choice should be a passenger lift, then a platform lift and lastly, a stair lift. Note that acceptance of a stair lift is subject to consultation with the fire service, to ensure its efficiency (Wilkinson, 2018). To summarise Part $\mathrm{M}$ of The Building Regulations, it states that people, regardless of disability, age or gender, should be able to: gain access to buildings, gain access within 
buildings, and use their facilities, both as visitors and as people who live or work within them.

British Standard BS 8300 was updated in 2018 and is now separated into two parts. Part 2 deals with entrances, reception facilities, horizontal and vertical movement, and facilities in the building. Previous editions of BS 8300 advised specifically on designing for disabled people. The new BS 8300-2 explains how to design, build and manage the built environment in a way that is inclusive to all. The fundamental idea is that designing to address and integrate the access requirements of all people, irrespective of their personal circumstances, is always preferable to designating separate or specific features.

\section{CASE STUDY FINDINGS AND DISCUSSION}

Over the four-week period of the case study, a total of 68 observations were recorded of ablebodied people using the doorway designed for disabled persons at a large multi-storey educational building, using the convenience sampling technique as a non-probability method (cf. Speak et al., 2018). Seven persons refused to participate on the grounds that they were either in a hurry or late for classes, hence the sample represented a $90.66 \%$ response rate. Of those who participated, 37 were male $(54.42 \%)$ and 31 were female (45.58\%). Five participants were staff $(7.35 \%)$, six participants were non-staff (e.g. delivery couriers) $(8.82 \%)$ and 57 participants were students (83.83\%). Structured interviews were held with each participant to ask three core questions, namely: i) Why did you use the disabled persons doorway?; ii) Would you have used the doorway had you known the negative impact upon the building's energy performance?; and iii) What control measures would you employ to discourage building users from using the disabled doorway?. The qualitative responses were manually recorded and codified (cf. Lemos et al., 2018) into six thematic groupings of the rationale for using disabled doorways, viz: i) apathy; ii) convenience; iii) ignorance; iv) emergency; v) ergonomics; and vi) phobia (refer to Table 1). These groupings represented a tabular taxonomy where the responses within could be numerated into frequencies and percentages for brevity.

$<$ Insert Table 1 about here $>$

\section{Apathy}


Eight participants $(11.77 \%$ of the sample) were classified under the apathy grouping. They revealed no concern for other disabled users or for preserving the building's energy consumption. When questioned, typical responses included: "I'm just a bit lazy really..." and "it's just easier to get into the building." These responses could be defined as indicative of 'psychological egoism' (cf. Sonne and Gash, 2018) and further education of building users is required to ensure that all visitors to the premises are considerate of the physical needs of others.

\section{Convenience}

By far the largest proportion of the sample (with 45 participants or 68\%) was classified under the aptly titled grouping of convenience theory (cf. Gotteschalk, 2018). Two main reasons were apparent. First, during peak times of the day when lecture classes finish, a large volume of students and staff (as many as circa 39-40 people) gather in the foyer area just in front of the rotating doors in order to exit the building, whilst simultaneously, other building users (of a lesser volume) are attempting to enter the building. This creates frustration, as identified by 25 participants interviewed, particularly for building users who have to move between buildings to attend other classes, present lectures or be present at a social event. One staff member who attempted to access the building typified the general feeling of frustration: " $[I$ used the disabled access]...because a large group of students were using the rotating door and I needed to get in quickly for a class - I just cannot be late."

Second, inclement weather constituted another major root cause of disabled door access and egress. During the observation period there were days of heavy downpours of rain, sometimes with accompanying gusts of wind which created sheets of almost vertical rainfall that was most unpleasant for people commuting between buildings and consequently, influenced their behaviour. Three participants agreed that in bad weather they just want to enter the building as quickly as possible. Six users implied that they did not want to wait in the queue to use the doors (given the prevailing weather) so preferred to use the disabled access. Seven others said that they simply followed other students/staff who had opened the disabled doorway and that it was quicker to follow on than stand in the inclement weather conditions. One student said: "I was getting absolutely drenched out there. All of my clothes, books and laptop bag are soaking wet and I am worried that I may ruin my lappy [laptop] if I would have been politely standing there waiting for people leaving the building and taking 
their time about it chatting - they're not getting wet!" Four other users said that they were in deep conversation and wanted to continue with it while walking into the building, rather than being split up using the revolving doors.

\section{Emergency}

During the survey two incidents classed as emergencies were recorded $(2.94 \%$ of the sample). The first incident involved a female postgraduate student who had apparently (according to her awaiting friends) had a severe anaphylactic shock (although this could not be confirmed) and being asthmatic, required emergency attention. One ambulance crew member assisted the student into the ambulance whilst the other carried her belongings; both used the disabled doorway. One female friend of the student said: "Anon [the student] had been pushing herself hard to get good grades as she wanted at least a 2.1 degree and had been working long hours to achieve the best grades. We did tell her to slow down but she's stubborn and won't listen - I think she has pressure from her parents at home." The second incident involved a male student who appeared to be intoxicated with alcohol and not in full control of his motor neurone system. Two male friends were accompanying the student and supporting him in a standing position between them. After several attempts to exit the building via the rotating doors they finally exited via the disabled doorway; when questioned, it was apparent that all three men had been drinking and celebrating the intoxicated student's 21 st birthday.

\section{Ergonomics}

Three recorded examples $(4.41 \%)$ which related to ergonomics included two instances of tradesmen carrying boxes of goods into the building and one of a lecturer who similarly had both hands full with large boxes of marked coursework. One tradesman said: "It's [the building] a really daft design - I've got a trolley full of boxes here and cannot possibly get through that revolving doorway - you'd think that they would think about people delivering things to the University. All they seem to care about is having a shiny building that looks nice." The lecturer agreed when she said: "We need to get the basic design and functionality of the building right - a building that is fit for purpose and doesn't just look good from the outside. It's a basic need to access and egress our place of work. My hands were full with boxes so I used my foot to open the door [by pushing the power assisted activation button]." 


\section{Ignorance}

Eight people (11.76\%) claimed ignorance of the impact that using a disabled access and egress doorway would have upon the building's energy performance. One student said: "I didn't know that there was a problem using the door and others use it too" - a response that indicates an element of crowd psychology (Filingeri et al. 2017), e.g. following what others do. Several other students indicated that having been informed of the ramifications of their building user behaviour, they would try to avoid using the disabled access and egress route henceforth. One student said: "I consider myself to be an environmentalist, and I've been a vegetarian for years - I just didn't know that my habit [using the disabled doorway] was causing a problem..."

\section{Phobia}

Two students (2.94\%) who entered the building simultaneously (and appeared to be friends one male, one female) claimed that they had a phobia of using the rotating doors (namely, claustrophobia) which prompted anxiety and caused the behavioural trait of avoidance (Carpenter et al., 2019). The male student said: "I always use it as I don't like the revolving doors - I'm a bit claustrophobic." The female student concurred and added: "It doesn't help when a stampede of students is coming in the opposite direction and it just makes you feel trapped - especially when they are pushing harder in the opposite direction. Doors are just so easy and simple to use."

\section{FEEDBACK ON POTENTIAL SOLUTIONS}

Influencing building user behaviour is a complex issue that requires a careful balance of various control measures, such as education and regulation. To determine which control measures resonate most with building users, a two-pronged line of enquiry was followed. First, study participants were invited to offer their own constructive comments and suggestions for changing building user behaviour. Second, a senior member of the building's facilities management team was invited to review the research findings and offer additional comment and suggestions via unstructured interview.

\section{Feedback from study participants}

Of the 68 study participants, 47 responses were received which represented $69.11 \%$ of the total population. Within this sample, more than one suggested control measure was proffered. 
Responses were manually codified and categorised within four thematic groupings, namely: education; regulation; obtrusive design features; and unobtrusive design features.

\section{Education}

Education was expressed as the main control measure by 35 survey participants (50\%). Increased communication with building users (both staff and students) about the performance and environmental ramifications of using the disabled access doorway was an integral part of this suggestion. Suggested measures included: standing at the door and talking to people directly; using a pin board in the library to warn people of the energy wastage caused by using this door; and sending a blanket email to all students and staff informing them of the issues associated with using the disabled access door unnecessarily. To encompass all users (including visitors), suggestions included: placing clear signage on both sides of the door asking people to only use it if necessary; placing posters around the university to educate building users; and displaying information on display screens around the university.

\section{Regulation}

More stringent regulations were stipulated as a suitable control measure by 20 survey participants $(28.57 \%)$. It was suggested that at the start of each term, lecturers should remind students only to use the disabled access door if absolutely necessary and that casual usage was strictly prohibited. Other participants suggested that stringent fines should be enforced as such behaviour was disrespectful and inconsiderate of the needs of disabled students and colleagues.

\section{Obtrusive design features}

Physical control measures were recommended by 10 survey participants (14.29\%). One participant suggested using an electronic chip in the card of disabled staff members or students to give them sole access to the doorway. Radio frequency identification tags (RFID), for example, have previously been widely used within industry (cf. Riaz et al., 2006; Edwards et al., 2018) and may have some applicability in this present context. The limitation however, is that disabled persons who seek to access the building but are not registered with the University scheme would effectively be barred - such could lead to complaints and fines for not being socially inclusive. Another option suggested was to have a full time security guard monitor the use of this doorway; the argument was made that security officers are 
present in the foyer anyway, so an extra job in this respect would not be too demanding or costly. Such would overcome the limitations of the previous idea given.

\section{Unobtrusive design features}

A relatively small number of respondents (5, representing 7.14\%) recommended the use of unobtrusive design features. One option included design so that the disabled doorway opened even more slowly to make this route of access and egress less appealing. Another option included redesigning the doorway to include two doors - the first to allow access to a retaining area that contained a second doorway which could only be opened when the first had closed. One student suggested that this could be called a purgatory zone - whilst the terminology may not be right, the idea seems to have some merit as it would prevent doorways being opened and reduce heat loss.

\section{Feedback from the Building's Carbon and Energy Reduction Manager}

To add validity to the study findings, the building's Carbon and Energy Reduction Manager (CERM) was presented with the analysis results to garner feedback as well as generate alternative perspectives. Whilst the CERM was a relatively new recruit to the building's facilities management team (having accrued only 11 months of experience working in the current position), they had previously worked for six years at another higher education institutethe University of Lincoln as an energy manager which was described as: “...the same role but with a different title." Based upon the historical knowledge accrued, it was agreed that the CERM had sufficient knowledge and experience to add an insightful contribution to the study.

The CERM was first asked whether advertisement of energy consumption levels on visual display screens within the building would be effective in preventing able-bodied users from using the disabled access door. The CERM said:

\footnotetext{
"Yes if you could come up with something which was visually impactful then that could be great. It needs to be something obvious from looking at otherwise people wouldn't notice it, as people do not spend long looking at the screens, it is only as they walk past. It is a fairly complex idea to distil into a single image. People don't always make the connection between points of ingress into a building and heat loss."
} 
"Posters on TV screens or printed out on paper both have similar limitations. They are viewed very momentarily. One advantage with a screen is that you put more information on different screens, but it is whether people would actually stop and look at it for that length of time. If we are looking at saving energy in buildings through making entrances more effective are we creating another problem by using energy to power a screen or print off posters? It would be interesting to do an environmental impact assessment of these two methods which could be a point of further research."

In response to the two former questions, the CERM was then asked whether verbal information from lecturers would be effective. The CERM said:

\begin{abstract}
"When I have previously interviewed students about environmental concerns one thing I have heard quite a lot is that students really seem to appreciate face to face verbal communication compared to other communication channels. That seems to have the most impact out of any of the communication channels. Obviously you are then restricted with how many people you can communicate with. A greeter could stand at the door during busy periods and could say to students that you should use the other door if possible. People can respond to that, maybe they have never made that connection before. If students have got questions then they can ask questions or make comments. This would be more interactive than on a screen or poster."
\end{abstract}

The CERM was finally asked about their views and opinions regarding physical deterrents and specifically whether design changes to the door would be effective? It was proposed that 'two power assisted doors' could be used to provide a hermetically sealed lobby area that would not allow passage through the second door until the first door had closed. In response, to this suggested building alteration, the CERM said:

"Well, with the wind lobby design, there are not many in the UK. The two doors seem to be triggered at the same time, so are not effective in slowing people down while entering or leaving a building. If another door was not line with the original door then this offset helps impede the triggering and heat transfer in the area. It would not trigger the doors at the same time. Expanding the size of the revolving door would be a better idea. If you had a bigger 
revolving area then you could get two or three people in at a time as there would be a bigger revolving area. This could be efficient for wheelchair users too. However you might still need the single door for legalities in case there is an emergency, but access could be restricted if needed. There is a fundamental flaw with the design of wind lobby doors as they cannot cope with volume."

Summed up for brevity, the CERM felt that education of building users was essential but that the second door system would not work well and instead proposed that the incorporation of a larger revolving door system for all building users would work better.

\section{RESEARCH IMPLICATIONS}

The rResearch findings presented within this paper have implications for both theory and practice.

\section{Theoretical implications}

In terms of theory development, the inductive research implemented raises a number of new theories on erroneous building user behaviour that now require future testing using a deductive approach and empirical primary data. Specifically, user behaviour and the impact upon building energy performance must be defined and delineated more explicitly using both energy consumption rates and the financial ramifications involved together with occupant behaviour. Given that the climate change agenda is of paramount importance to governments globally (Li et al., 2019), such future work proposed could have a dramatic impact upon energy consumption rates and the wider education of building users. In particular, building users must be better educated about how their behaviour can reduce their (and the building's) environmental impact. Various pragmatic options and techniques are available to engender proactive environmental behaviour such as creating a psychological sense of ownership or reinforcing good habit formation (c.f. White et al., 2019). It is most likely that a coalescence of these techniques will derive the optimum result.

\section{Practical implications}

From a practical perspective, the research identifies that building user behaviour must be considered more prominently at the 'design stage' of a building's lifecycle. At this juncture, both the architect and client should work closer together to ensure that the future design of a building is fit for purpose and can accommodate the anticipated influx of building users at 
peak times without compromising the building's energy performance. However, herein resides an important conundrum that requires some further consideration. For example, i larger buildings where a higher flow of building users through access and egress routes in anticipated at peak times (such as at the start or end of a work shift), doorways should be capable of facilitating this flow rate of people. To deliver reliable estimates of peak building access and egress engender such proposed work wwill require multidisciplinary teams of academics to incorporate (for example) aspects relating to: the building's design (from both aesthetic and utilitarian perspectives) (Aydin et al., 2019); occupant usage (to measure and record occupant pheromone trails and peak flow times) (Xia et al., 2019); and building's type, maintenance requirements and functionality (that is, how the building is being used and any vagaries associated with this usage) (Prieto et al., 2019). Moreover, such work will require substantial longitudinal research projects to collect sufficient data to observe, report upon and model any trends apparent. Perhaps this is where a more robust post occupancy evaluation (cf. Roberts et al., 2020) would provide primary data (and hard evidence) to support the refinement of future designs created by an architect in the client's brief but also ensure a soft landing (cf. Pärn et al., 2017).

\section{CONCLUSIONS}

A bibliometric review of literature within the topic area reveals that scant academic research has hitherto been conducted to explain the reasoning behind building occupants' erroneous usage of disabled access and egress routes for a building. Yet, such behaviour could severely reduce the environmental performance of buildings, as well as inconvenience disabled users. The design of every building in the UK must adhere to regulations set out in The Equality Act, Part M of the Building Regulations and the British Standard BS 8300. By using the power assisted door, the building's hermetic seal is broken and unnecessary energy is consumed (and pollution generated) as a consequence. By conducting a case study on a large multi-storey educational building located in the city of Birmingham, UK, it is apparent that six thematic groupings explain able-bodied users' erroneous behaviour namely: apathy, convenience, emergency, ergonomics, ignorance and phobia.

Building upon these findings and following discussions with participants and the building's CERM, mitigation measures proposed to change building users' erroneous behaviour could include a mixture of education, regulation, unobtrusive design features and obtrusive design 
features. These approaches include: the education of building users on the impact their behaviour has upon building performance and environmental pollution; more stringent regulation to penalise repeat offenders; and changes to building entrance design using obtrusive (i.e. a larger and singular revolving doorway and/or radio frequency identification tags for building users) and unobstrusive control measures (i.e. a second entrance doorway or a slower opening mechanism - both of which serve to discourage able-bodied users). Of these, the recommendation for a singular revolving door system that is large enough for ablebodied and disabled users would appear to be the most viable and practical measure. Cumulatively, the findings provide members of the building's facilities management team with both reasons for erroneous usage of disabled doorways and also potential applied solutions. This simple solution could also yield a much needed improvement in building energy performance to reverse the current upward trend.

However, the research presented is indicative vis-à-vis definitive, in the treatment of the phenomena under investigation, mainly due to the relatively small sample size collected for this study. Furthermore, the educational context of the study was bounded by a predominantly 'young student population' who occupied the building. Other building types may well produce significantly different results and thematic categorisations than those presented here. Perhaps the major limitation of the work resides in the fact that the study has yet to calculate the additional energy consumed (and associated cost of this) to maintain internal temperatures as a result of a disabled doorway opening erroneously. Hence at this juncture, it remains an unproven thesis that such activity could contribute significantly to increasing the building's energy consumption and environmental performance. Future research is therefore required to: i) expand the scope of buildings surveyed, as well as the age and occupation of occupants, in order to achieve a more balanced and complete perspective of disabled doorway usage; and ii) quantify energy wasted (both in consumption rates as well as associated financial expenditure) via the use of virtual or augmented reality to test the various design options that could discourage use of disabled doorways and determine what the optimum design could be. It would be advisable that such work should be conducted before any physical redesign or modification of the building is made to measure the success or otherwise of chosen designs when implemented in practice. Hence, a post occupancy evaluation of a current building's design (and client brief) and performance should better inform the design and energy efficiency of future building designs. 


\section{REFERENCES}

Allan, N., Gill, Z.M., Pegg, I.M. and Tierney, M.J. (2010) Low-energy dwellings: the contribution of behaviours to actual performance, Building Research \& Information, Vol. 38, No. 5, pp. 491-508. DOI: https://doi.org/10.1080/09613218.2010.505371

Allcott, H., Mullainathan,S. (2010) Behavior and energy policy, Science, Vol 327, No 5970, pp. 1204-1205. DOI: https://doi.org/10.1126/science.1180775

Al-Saeed, Y., Pärn, E.A., Edwards, D.J. and Scaysbrook, S. (2019) A conceptual framework for utilising bim digital objects (BDO) in manufacturing design and production: a case study. Journal of Engineering Design and Technology. [available on-line]. DOI: https://doi.org/10.1108/JEDT-03-2019-0065

Al-Saeed, Y., Edwards, D.J. and Scaysbrook, S. (2020) Automating construction manufacturing procedures using BIM digital objects (BDO): case study of knowledge transfer partnership project in UK, Construction Innovation [in-press].

Aydin, Y.C., Mirzaei, P.A. and Akhavannasa, S. (2019) On the relationship between building energy efficiency, aesthetic features and marketability: Toward a novel policy for energy demand reduction, Energy Policy, Vol 128, pp. 593-606. DOI: https://doi.org/10.1016/j.enpol.2018.12.036

Bitar, E.Y., Khargonekar, P.P., Poolla, K., Rajagopal, R., Varaiya, P. (2012) Bringing wind energy to market, IEEE Transactions on Power Systems, Vol. 27, no. 3, pp. 12251235. DOI: https://doi.org/10.1109/TPWRS.2012.2183395

Bostic, J.D., Matney, G.T. and Sondergeld, T.A. (2019) A validation process for observation protocols: Using the Revised SMPs Look-for Protocol as a lens on teachers' promotion of the standards, Investigations in Mathematics Learning, Vol. 11, No.1, pp. 69-82. DOI: 10.1080/19477503.2017.1379894

Bourgeois, D., Macdonald, I. and Reinhart, C. (2006) Adding advanced behavioural models in whole building energy simulation: a study on the total energy impact of manual and automated lighting control, Energy and Buildings, Vol 38, No 7, pp. 814-823. DOI: https://doi.org/10.1016/j.enbuild.2006.03.002

BSI (2018) Design of an accessible and inclusive built environment. Buildings. Code of practice, London: British Standards Institution.

Cali, D., Andersen, R.K., Mueller, D. and Olesen, B.W. (2016) Analysis of occupants' behavior related to the use of windows in German households, Building and 
Environment, $\quad$ Vol. $\quad 103, \quad$ pp. 54-69, DOI: https://doi.org/10.1016/j.buildenv.2016.03.024

Carpenter, D., Young, D. K., Barrett, P. and McLeod, A. J. (2019) Refining technology threat avoidance theory, Communications of the Association for Information Systems, Vol. 44, Paper No. 22, pp. 380-407. DOI: https://doi.org/10.17705/1CAIS.04422

Chamberlain, D., Edwards, D.J., Lai, J. and Thwala, W.D. (2019) Mega event management of formula one grand prix: an analysis of literature. Facilities. Vol. 37, No. 13/14, pp. 1166-1184. DOI: https://doi.org/10.1108/F-07-2018-0085

Cobo, M.J., Herrera-Viedma, E., Laengle, S., Merigó, J.M., Rivas, D. (2018) Twenty years of Soft Computing: a bibliometric overview, Soft Computing.

Dawson, J., Dummett, Fitzpatrick, R Jenkinson, C S., Kelly, L. (2013) Development of the Oxford Participation \& Activities Questionnaire: Semi structured interviews with potential users, Journal of the Neurological Sciences, vol. 333, pp. e651-e651

de Bakker, C., Aries, M., Kort, H. and Rosemann, A. (2017) Occupancy-based lighting control in open-plan office spaces: A state-of-the-art review, Building and $\begin{array}{llll}\text { Environment, } & \text { Vol. } & \text { 112, } & \text { 308-321. DOI: }\end{array}$ https://doi.org/10.1016/j.buildenv.2016.11.042

Edwards, D. J. and Love, P. E. D. (2016) A case study of machinery maintenance protocols and procedures within the UK utilities sector. Accident Analysis and Prevention, Vol. 93, pp. 319-329. DOI:10.1016/j.aap.2015.10.031

Edwards, D. J., Pärn, E. A., Love, P. E. D. and El-Gohary, H. (2017) Machinery, manumission and economic machinations, Journal of Business Research, 70, pp. 391394. DOI: https://doi.org/10.1016/j.jbusres.2016.08.012

EPBD (2010) Energy Performance of Buildings Directive (EPBD) 2010/31/EU of the European Parliament and of the Council of 19 May 2010 on the energy performance of buildings (recast) [Online]. Official Journal of the European Union, Available at: https://eur-lex.europa.eu/legal-content/EN/TXT/?uri=celex:32010L0031 Accessed $1 / 05 / 19$.

Filingeri, V., Eason, K., Waterson P., Haslam R., (2017) Factors influencing experience in crowds - The participant perspective, Applied Ergonomics, Vol. 59, pp. 431-441. DOI: https://doi.org/10.1016/j.apergo.2016.09.009 
Fisher, L., Edwards, D. J., Pärn, E. A. and Aigbavboa, C. O. (2018) Building design for people with dementia: a case study of a UK care home. Facilities, Vol. 36, No. 7/8, pp. 349-368. DOI:10.1108/F-06-2017-0062

Giménez-Espert, M. del C. and Prado-Gascó, V.J. (2019) Bibliometric analysis of six nursing journals from the Web of Science, 2012-2017, JAN Leading Global Nursing Journal, Vol. 75, No. 3, pp. 543-554. DOI: https://doi.org/10.1111/jan.13868

Goel, A., Ganesh, L.S. and Kaur, A. (2019) Sustainability assessment of construction practices in India using inductive content analysis of research literature, International Journal of Construction Management, [available on-line]. DOI: $10.1080 / 15623599.2019 .1583851$

Gottschalk, P. (2018) Approaches to the empirical study of convenience theory for whitecollar crime, Deviant Behavior, Vol. 39, No. 12, pp. 1600-1614, DOI: https://doi.org/10.1080/01639625.2017.1410623

Hosseini, M. Reza, Cao, D., Oraee, M., Edwards, D.J., Li, H. and Papadonikolaki, E. (2019) Collaboration Barriers in BIM-based Construction Networks: A Conceptual Model. International Journal of Project Management. Vol. 37, No. 6, pp. 839-854. DOI: https://doi.org/10.1016/j.ijproman.2019.05.004

Jenkins, K., McCauley, D., Sovacool, B.K. (2018) Humanizing sociotechnical transitions through energy justice: An ethical framework for global transformative change, Energy Policy, Vol. 117, pp. 66-74. DOI: https://doi.org/10.1016/j.enpol.2018.02.036

Jian, Y., Guo, Y., Liu, J., Bai, Z. and Li, Q. (2011) Case study of window opening behavior using field measurement results, Building Simulation, Vol. 4, No 2, pp. 107-116. DOI: https://doi.org/10.1007/s12273-010-0012-5

Lawrence, T.M., Boudreau, M-C., Helsen, L., Henze, G., Mohammadpour, J., Noonan, D., Patteeuw, D., Pless, S. and Watson, R.T. (2016) Ten questions concerning integrating smart buildings into the smart grid, Building and Environment, Vol. 108, pp. 273-283. DOI: https://doi.org/10.1016/j.buildenv.2016.08.022

Lemos, C., Pereira, M.T., Ferreira, L.P. and Silva, F.J.G. (2018) A codification system roadmap: case study in a metalworking company, Procedia Manufacturing, Vol. 17, pp. 688-695. DOI: https://doi.org/10.1016/j.promfg.2018.10.118

Li, D.H.W., Lam, J. and Yang, C.L. (2013) Zero energy buildings and sustainable development implications - A review, Energy, Vol. 54, pp. 1-10. DOI: https://doi.org/10.1016/j.energy.2013.01.070 
Li, H.X., Edwards, D.J., Hosseini, M. Reza., Costin, G.P. (2019) A review on renewable energy transition in Australia: an updated depiction. Journal of Cleaner Production. DOI: https://doi.org/10.1016/j.jclepro.2019.118475

Lu, M. and Lai, J.H.K. (2019) Building energy: a review on consumptions, policies, rating schemes and standards, Energy Procedia, Vol. 158, pp. 3633-3638. DOI: https://doi.org/10.1016/j.egypro.2019.01.899

Lucon, J.O, Ürge-Vorsatz D, Ahmed A.Z, Akbari, H, Bertoldi P, Cabeza L.F, Eyre, A. Gadgil, Harvey, L.D, Y. Jiang, E. Liphoto, S. Mirasgedis, S. Murakami, Parikh, C. Pyke, M.V. VilariÒo, (2015) Climate Change 2014: Mitigation of Climate Change. IPCC Working Group III Contribution to AR5 Chapter 9 - Buildings, Vol 3. International Institute for Applied Systems Analysis. DOI: http://pure.iiasa.ac.at/id/eprint/11117/

Martins, F.S., de Cunha, J.A.C. and Serra, F.A.R. (2018) Secondary data in research - uses and opportunities, Revista Ibero-Americana de Estratégia, Vol. 17, No. 4, pp. 1-4. DOI: https://doi.org/10.5585/ijsm.v17i4.2723

Mongeon, P. and Paul-Hus, A. (2016) The journal coverage of Web of Science and Scopus: a comparative analysis, Scientometrics, Vol. 106, No. 1, pp. 213-228. DOI: https://doi.org/10.1007/s11192-015-1765-5

Moran, P., Goggins, J. and Hajdukiewicz, M. (2017) Super-insulate or use renewable technology? Life cycle cost, energy and global warming potential analysis of nearly zero energy buildings (NZEB) in a temperate oceanic climate, Energy and Buildings, Vol. 139, pp. 590-607. DOI: https://doi.org/10.1016/i.enbuild.2017.01.029

Oh, J., Hong, T., Kim, H., An, J., Jeong, K. and Koo, C. and (2017) Advanced strategies for net-zero energy building: focused on the early phase and usage phase of a building's life cycle, Sustainability, Vol. 9, No. 12, pp. 2272, DOI: https://doi.org/10.3390/su9122272

Omer, A. (2008) Energy, environment, and sustainable building, Renewable and Sustainable Energy Reviews, Vol 12, No 9, pp. 2265-2300. DOI: https://doi.org/10.1016/j.rser.2007.05.001

Ouyang, J. and Hokao, K. (2009) Energy-saving potential by improving occupants' behavior in urban residential sector in Hangzhou City, China, Energy and Buildings, Vol. 41, No 7, pp. 711-720. DOI: https://doi.org/10.1016/j.enbuild.2009.02.003 
Owusu-Manu, D., Edwards, D. J., Adesi, M., Badu, E. and Love, P. E. D. (2016) Attaining fairness in construction cost consultancy pricing services: a case study in Ghana. Journal of Engineering Design and Technology, Vol. 14, No. 4, pp. 699-712. DOI:10.1108/JEDT-01-2015-0002

Pärn, E. A., Edwards, D. J. and Sing, M.C.P. (2017) The building information modelling trajectory in facilities management: a review. Automation in Construction, 75, pp. 4555. DOI:10.1016/j.autcon.2016.12.003

Prieto, A.J., Macías-Bernal, J.M., Chávez, M-J., Alejandre, F.J. and Silva, A. (2019) Impact of Maintenance, Rehabilitation, and Other Interventions on Functionality of Heritage Buildings, Journal of Performance and Constructed Facilities. Vol. 33, No. 2. DOI: 10.1061/(ASCE)CF.1943-5509.0001271

Riaz, Z., Edwards, D. J. and Thorpe, A. (2006) SightSafety: A hybrid information and communication technology system for reducing vehicle/pedestrian collisions. Automation in Construction, 15(6), pp. 719 - 728. DOI:10.1016/j.autcon.2005.09.004

Roberts, C. J., Edwards, D. J., Hosseini, M. Reza., Matzeo-Garcia, M. and Owusu-Man, D. (2019) Post occupancy evaluation: a critical review of literature. Engineering, Construction and Architectural Management, [available on-line]. DOI: https://doi.org/10.1108/ECAM-09-2018-0390

Rogelj, J., McCollum, D.L., Reisinger, A., Meinshausen, M. and Riahi, K. (2013) Probabilistic cost estimates for climate change mitigation, Nature: International Journal of Science, vol. 493, no. 7430, pp. 79-83. DOI: https://doi.org/10.1038/nature11787

Rosillo Callé, F. (2012) The biomass assessment handbook: bioenergy for a sustainable environment, London: Earthscan. ISBN-10: 1844075265

Seligman, C., Darley, J.M. and Becker, L.J. (1978) Behavioural approach to residential energy conservation. Energy and Buildings, Vol 1, No. 3, pp. 325-337. DOI: https://doi.org/10.1016/0378-7788(78)90012-9

Socolow, R. H. (1978) The twin rivers program on energy conservation in housing: Highlights and conclusions, Energy and Buildings, Vol. 1, No 3, pp. 207-242, DOI: https://doi.org/10.1016/0378-7788(78)90003-8

Sonderegger, R.C. (1978) Movers and stayers: the resident's contribution to variation across houses in energy consumption for space heating, Energy Buildings, Vol. 1, No. 3, pp. 313-324. DOI: https://doi.org/10.1016/0378-7788(78)90011-7 
Sonne, J. W. H. and Gash, D. M. (2018) Psychopathy to altruism: Neurobiology of the selfish-selfless spectrum, Frontiers in Psychology, Vol. 9: Article 575. DOI: 10.3389/fpsyg.2018.00575.

Speak, A., Escobedo, F.J., Russo, A. and Zerbe, S. (2018) Comparing convenience and probability sampling for urban ecology applications, Journal of Applied Ecology, Vol. 55, No. 5, pp. 2332-2342. DOI: https://doi.org/10.1111/1365-2664.13167

Stanek, J., Babkin, E,. Zubov, M. (2016) A new approach to configurable primary data collection, Computer Methods and Programs in Biomedicine, Vol. 133, pp. 169-181. DOI: https://doi.org/10.1016/j.cmpb.2016.05.007

Su, Y., Lan, S-C., Wei, K. (2012) Organic photovoltaics, Materials Today, Vol. 15, no. 12, pp. 554-562. DOI: https://doi.org/10.1016/S1369-7021(13)70013-0

Sunikka-Blank, M. and Galvin, R. (2012) Introducing the prebound effect: the gap be-tween performance and actual energy consumption, Building Research and Information, Vol. 40, No. 3, pp. 260-273. DOI: https://doi.org/10.1080/09613218.2012.690952

The Building Regulation (2010a) Access to and use of buildings Volume I [Online] Available at:

https://assets.publishing.service.gov.uk/government/uploads/system/uploads/attachme nt_data/file/540330/BR_PDF_AD_M1_2015_with_2016_amendments_V3.pdf Accessed: $15 / 11 / 18$

The Building Regulation (2010b) Conservation of fuel and power [Online] Available at: https://assets.publishing.service.gov.uk/government/uploads/system/uploads/attachme nt data/file/540326/BR PDF AD L1A 2013 with 2016 amendments.pdf Accessed 1/05/19

The Equality Act (2015) The Equality Act 2010. Edition 2015. Available at: https://www.gov.uk/guidance/equality-act-2010-guidance Accessed: 15/11/18

Wang, L.P. and Greenberg, S. (2015) Window operation and impacts on building energy consumption, Energy and Buildings, Vol 92, pp 313-321, DOI: https://doi.org/10.1016/j.enbuild.2015.01.060

Wang, S., Ku, C. and Chu, C. (2012) Sustainable Campus Project: Potential for Energy Conservation and Carbon Reduction Education in Taiwan, International Journal of Technology and Human Interaction (IJTHI), Vol. 8, No. 3, pp. 19-30. DOI: http://www.giee.ntnu.edu.tw/en/files/writing/788_d8cb7306.pdf 
Wang, Y., Shi, H., Sun, M., Huisingh, D., Hansson, L. and Wang, R., (2013) Moving towards an ecologically sound society? Starting from green universities and environmental higher education, Journal of Cleaner Production, Vol. 61, pp. 1-5. DOI: https://doi.org/10.1016/j.jclepro.2013.09.038

Wang, C., Yan, D. and Ren, X. (2016) Modelling individual's light switching behavior to understand lighting energy use of office building, Energy Procedia, Vol. 88, pp. 781787. DOI: $\underline{\text { https://doi.org/10.1016/i.egypro.2016.06.128 }}$

White, K., Habib, R. and Hardisty, D.J. (2019) How to SHIFT Consumer Behaviors to be More Sustainable: A Literature Review and Guiding Framework, Journal of $\begin{array}{lllllll}\text { Marketing, } & \text { Vol. } & 83, & \text { No. } & 3, & \text { pp. } & \text { 22-49. }\end{array}$ https://doi.org/10.1177/0022242919825649

Woo, S.E. O'Boyle, E.H. and Spector, P.E., (2017) Best practices in developing, conducting, and evaluating inductive research, Human Resource Management Review, vol. 27, no. 2, pp. 255-264, DOI: https://doi.org/10.1016/j.hrmr.2016.08.004

Xia, D., Lou, S., Huang, Y., Zhao, Y., Li, D.H.W., and Zhou, X. (2019) A study on occupant behaviour related to air-conditioning usage in residential buildings, Energy and Buildings, Vol. 203, DOI: https://doi.org/10.1016/j.enbuild.2019.109446.

Yun, G.Y., Kim, H. and Kim, J.T., (2012a) Effects of occupancy and lighting use patterns on lighting energy consumption, Energy and Buildings, Vol. 46, pp. 152-158. DOI: https://doi.org/10.1016/j.enbuild.2011.10.034

Yun, G.Y., Kong, H.J., Kim, H., Kim, J.T., (2012b) A field survey of visual comfort and lighting energy consumption in open plan offices, Energy and Buildings, Vol 46, pp. 146-151, DOI: https://doi.org/10.1016/j.enbuild.2011.10.035

Zhou, X., Yan, D., Hong, T.Z. and Ren, X. (2015) Data analysis and stochastic modelling of lighting energy use in large office buildings in China, Energy and Buildings, Vol. 86, pp. 275-287. DOI: https://doi.org/10.1016/j.enbuild.2014.09.071 
Figure 1a - The Educational Building

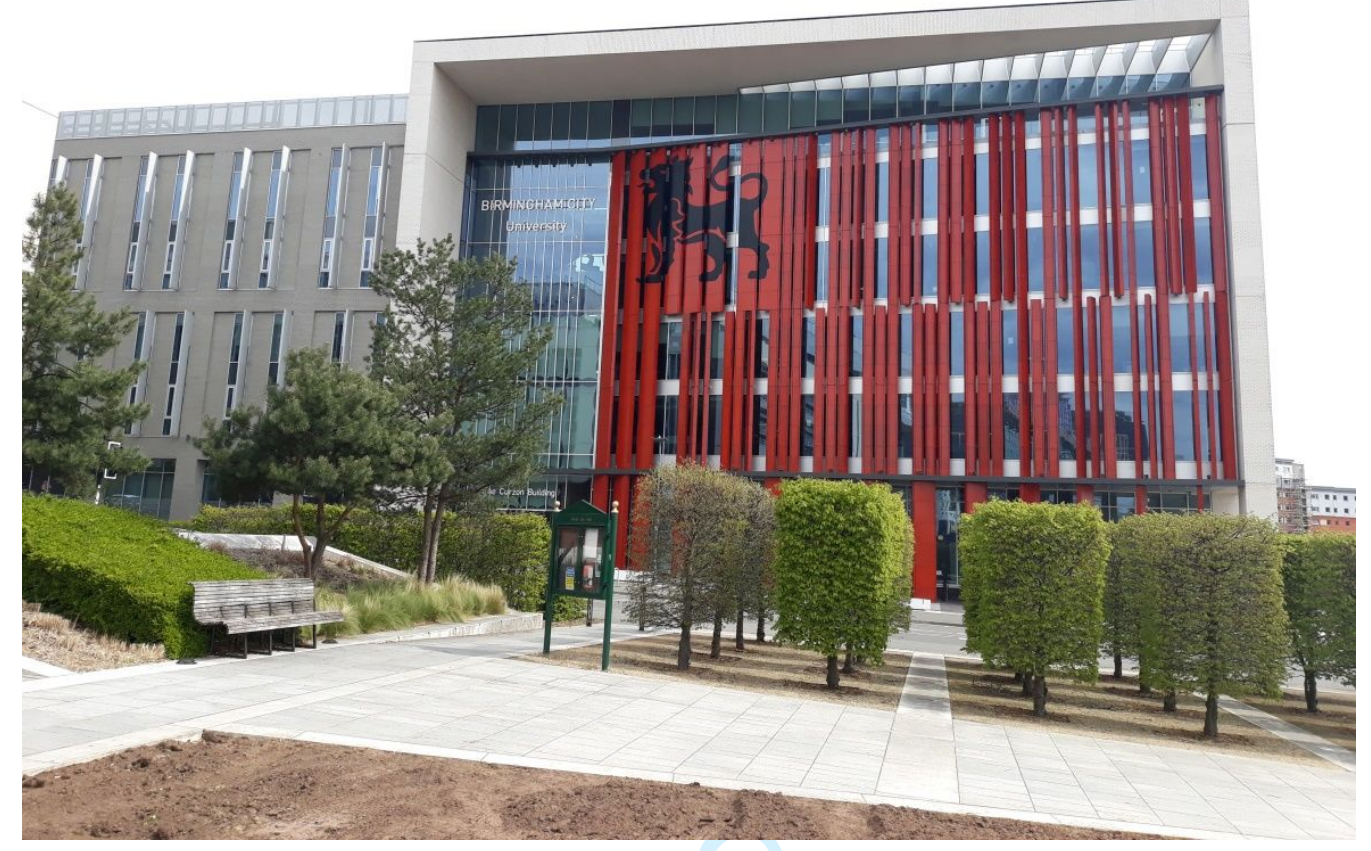

Figure 1b - The Entrance to the Educational Building

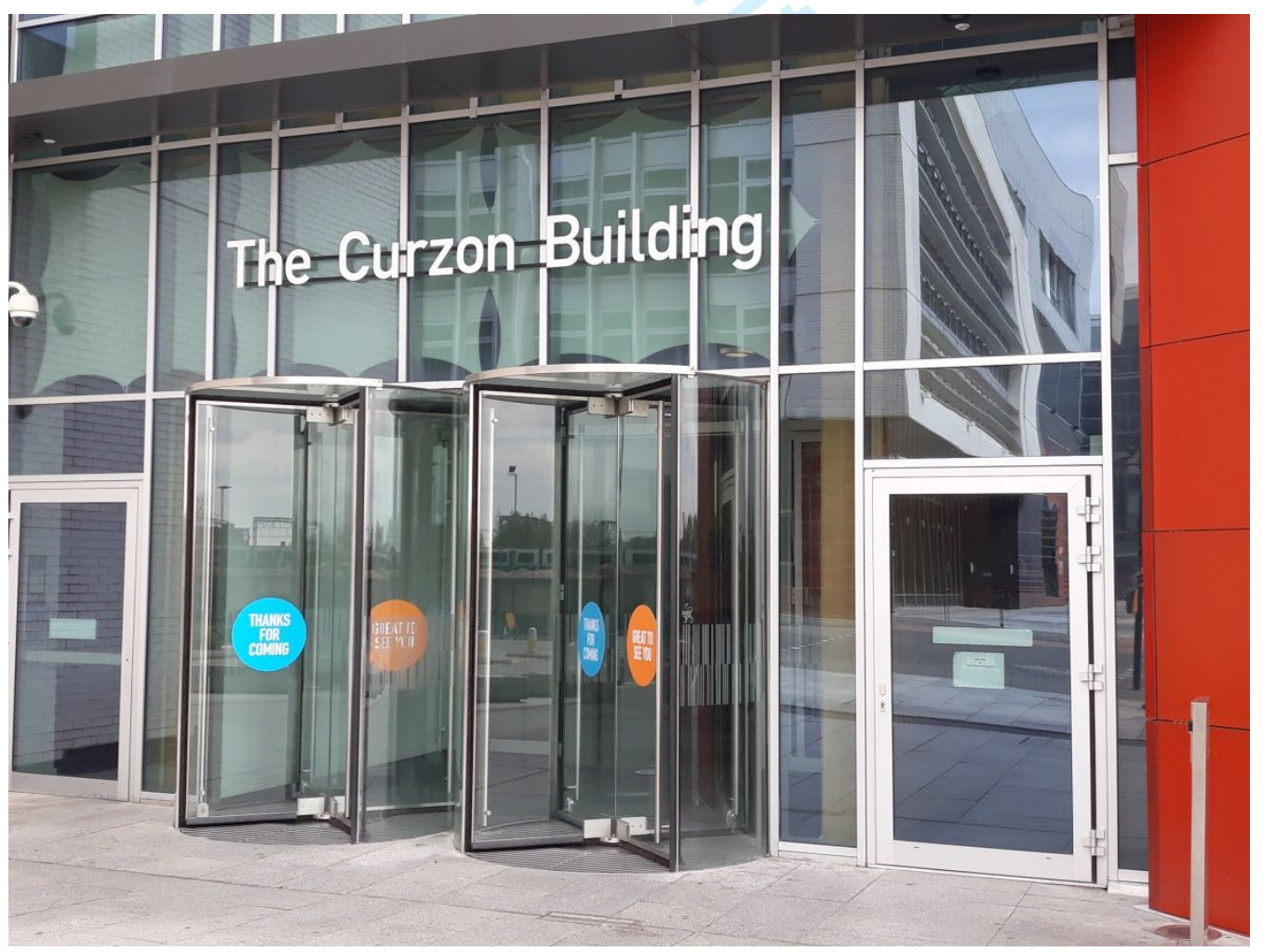


Figure 2 - Building Energy Consumption Trend

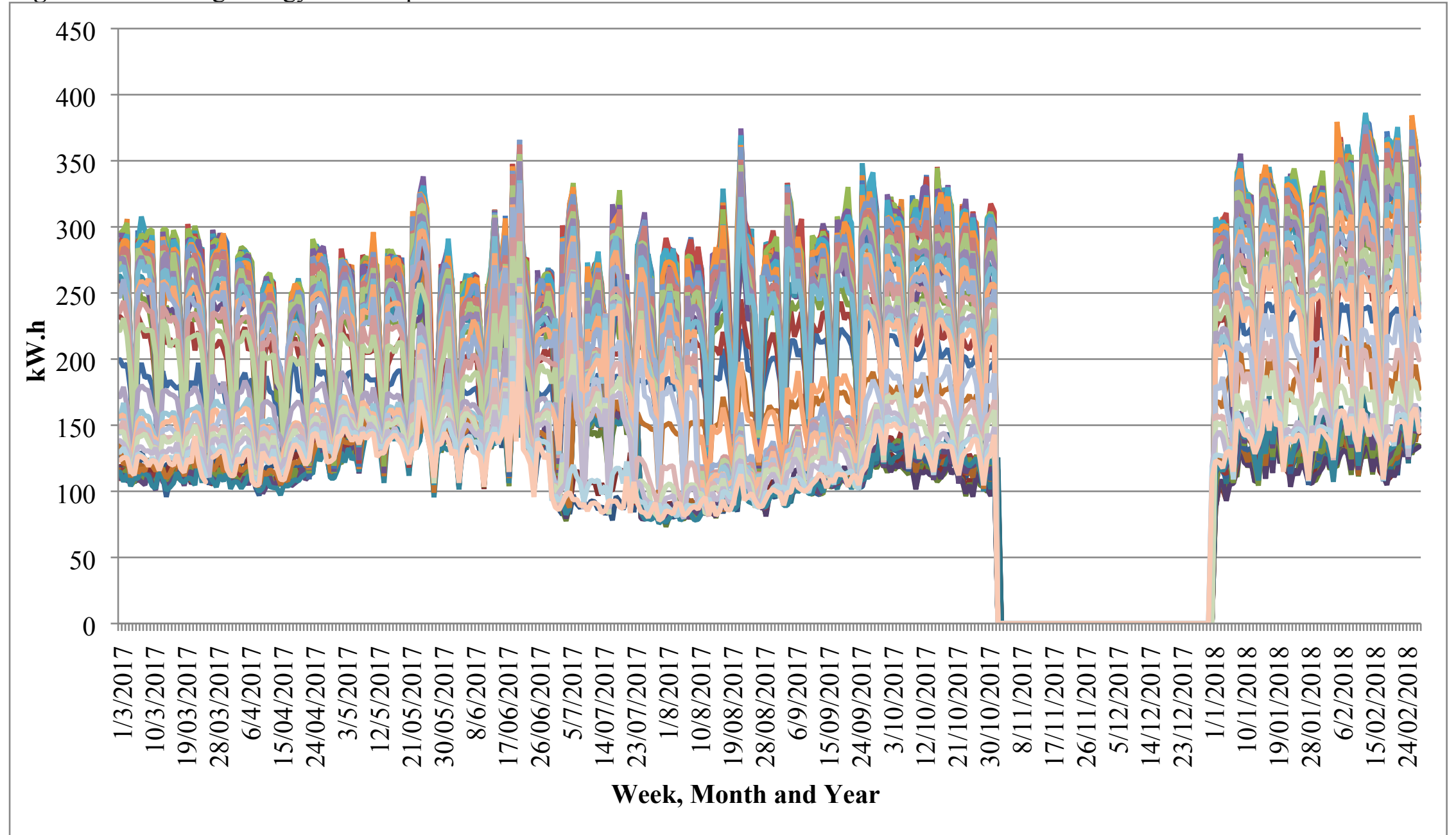

NB: Multiple values presented indicate that readings were taken each day at 30 minute increments. The period 8/11/2017 to $1 / 1 / 18$ is missing due to technical difficulties experienced. 
Figure 3 - Keyword Clusters

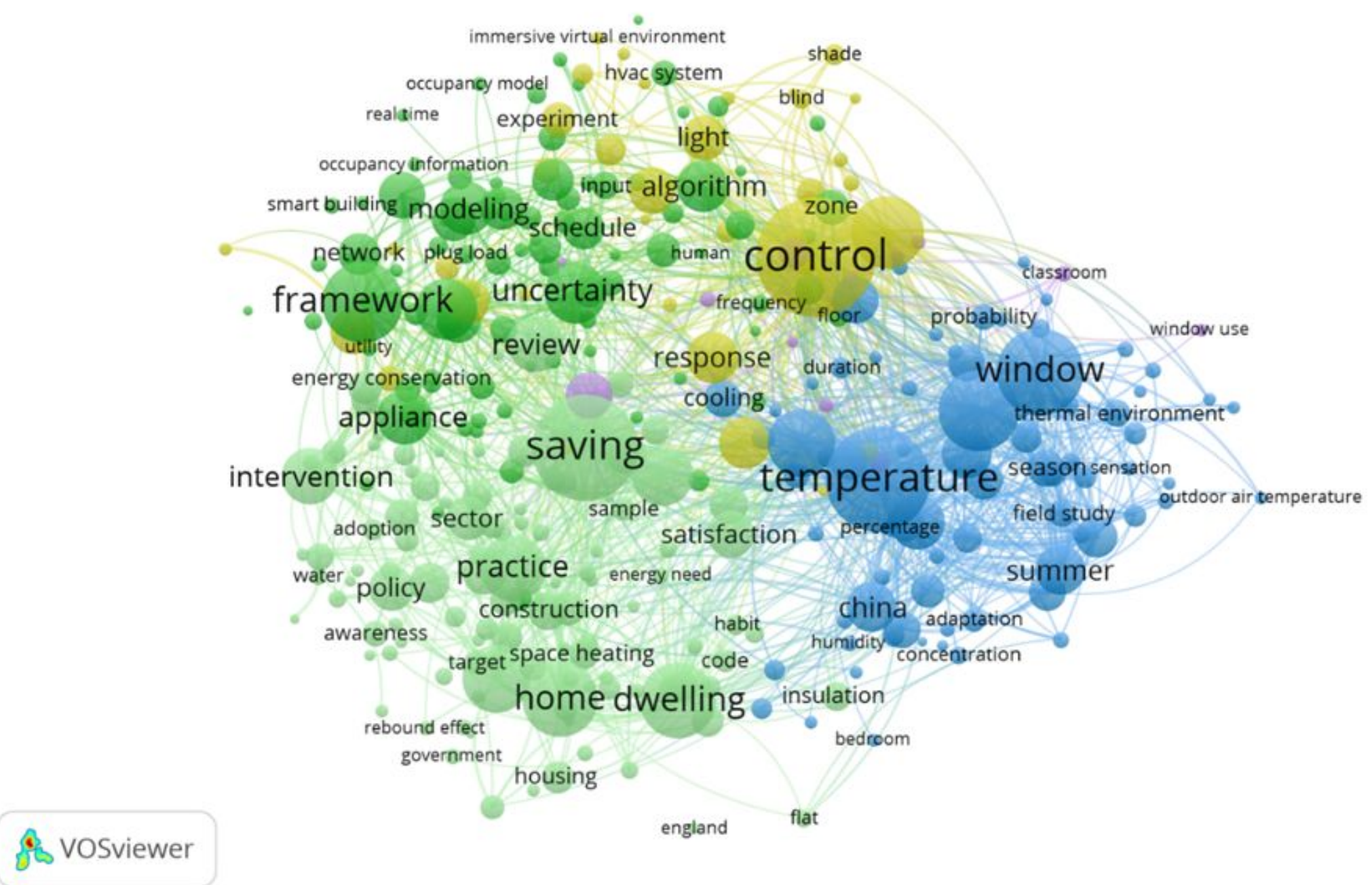


Figure 4 - Mapping of Prominent Journals in the Field

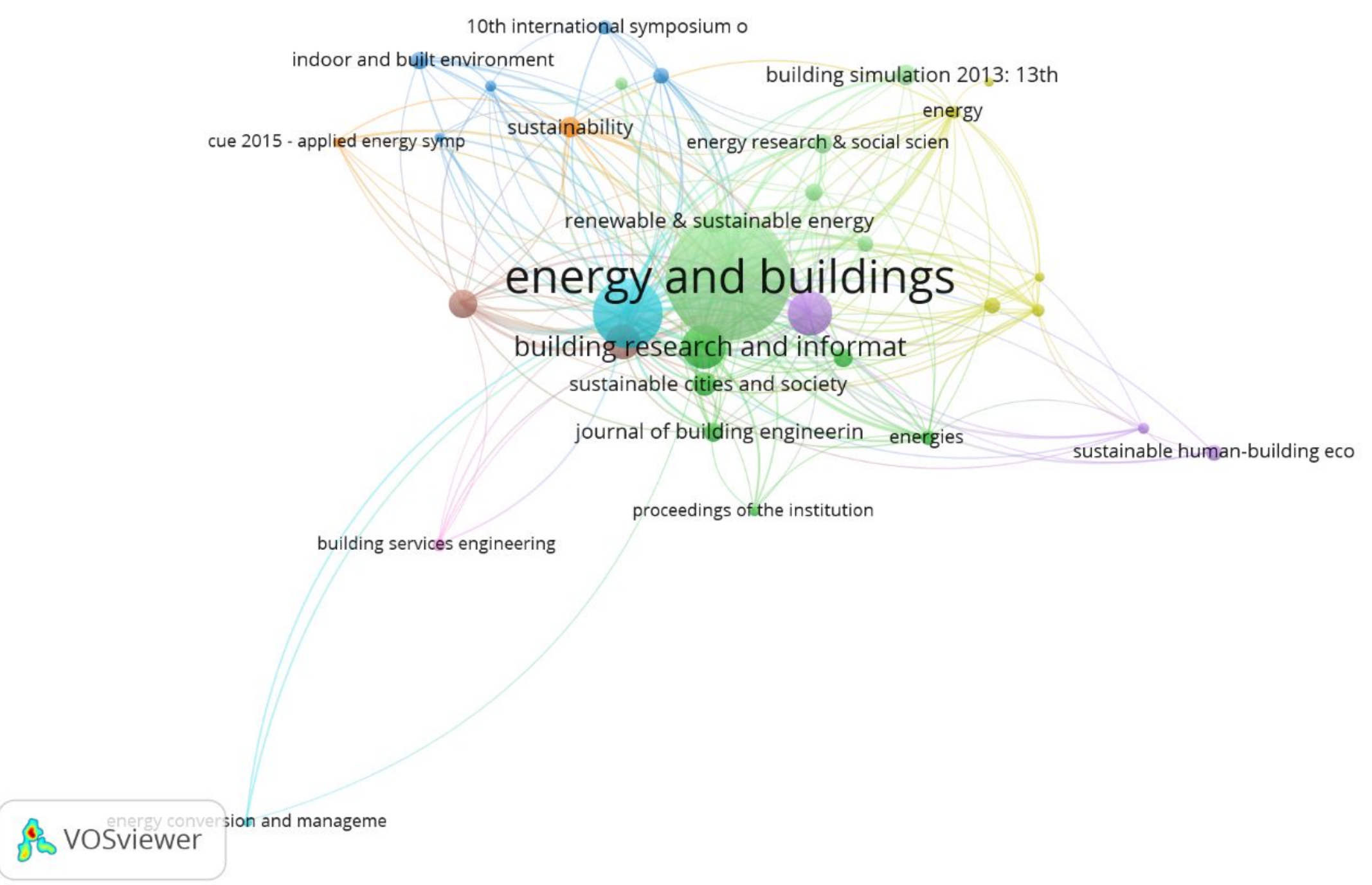


Figure 5 - Research Output by Country

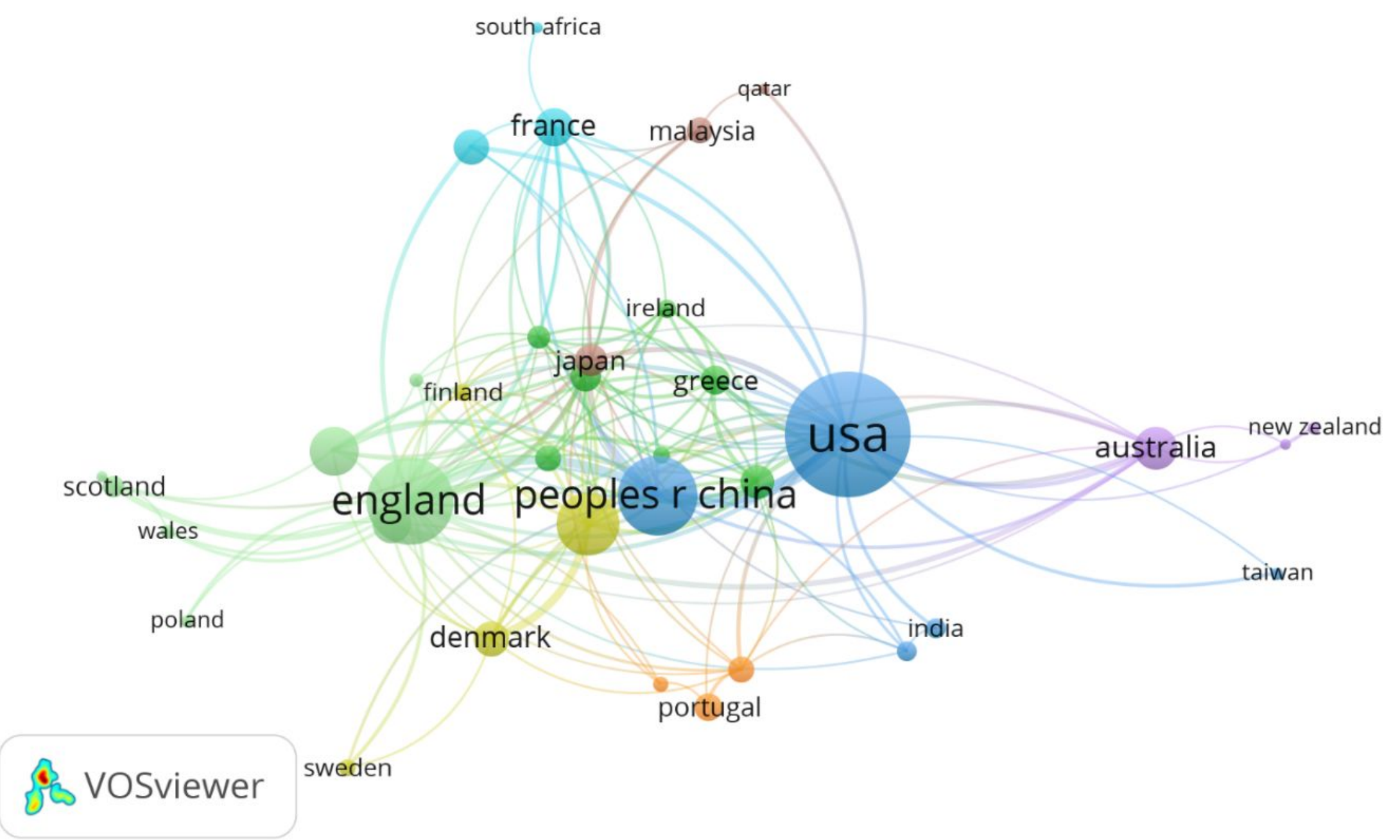


Figure 6 - Research Published by Institution

swiss fed inst technol

virginia tech

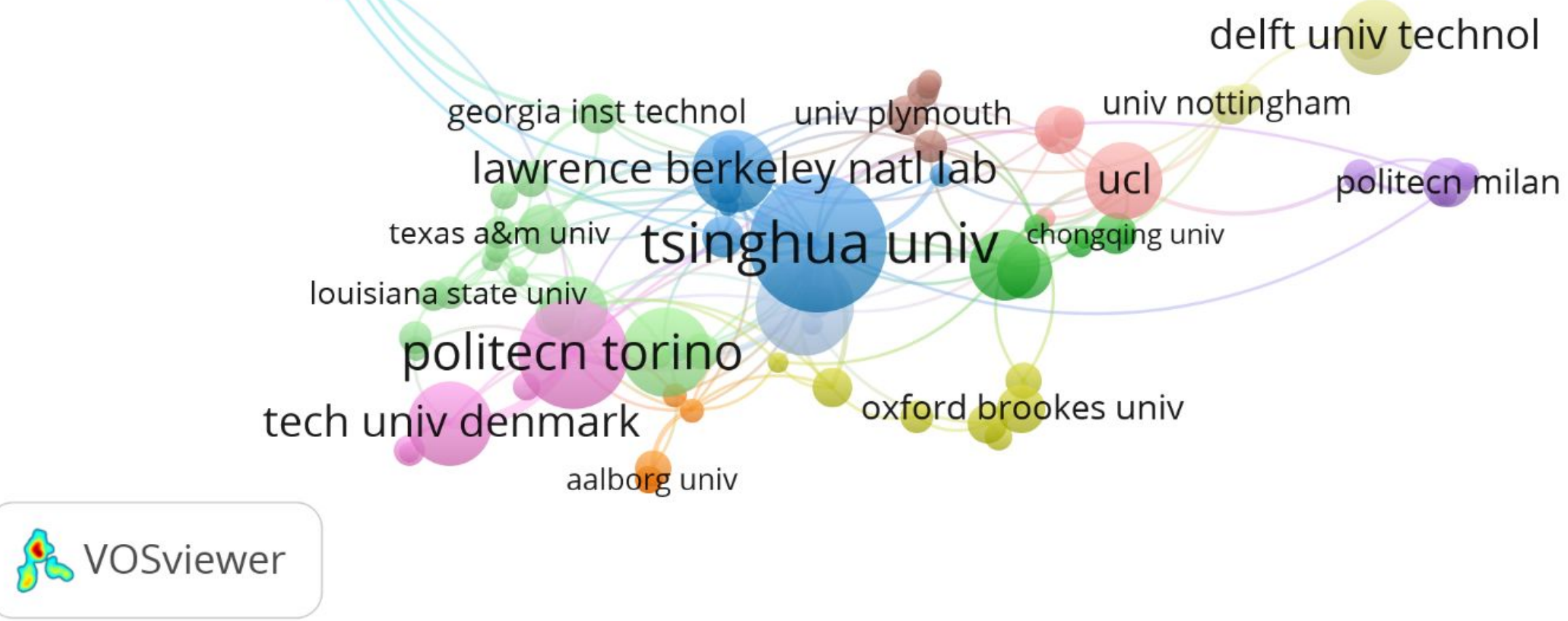


Table 1 - Tabulation of Reasons for using the Disabled Access/Egress Route

\begin{tabular}{|c|c|c|c|}
\hline Classification & Description & $\begin{array}{l}\text { Frequency } \\
(f)(\text { no. })\end{array}$ & $\begin{array}{l}\text { Percentage } \\
f(\%)\end{array}$ \\
\hline Apathy & $\begin{array}{l}\text { Persons give no consideration to the use of disabled } \\
\text { access and egress routes. }\end{array}$ & 8 & 11.77 \\
\hline Convenience & $\begin{array}{l}\text { Persons need to enter the building expediently - } \\
\text { e.g. during busy times of the day when queues of } \\
\text { people are waiting to use the rotating doors or } \\
\text { during inclement weather. }\end{array}$ & 45 & 66.18 \\
\hline Emergency & $\begin{array}{l}\text { Persons use the disabled access and egress routes } \\
\text { when carrying emergency equipment (e.g. a } \\
\text { student had an asthma attack and emergency } \\
\text { services were called to the building). }\end{array}$ & 2 & 2.94 \\
\hline Ergonomics & $\begin{array}{l}\text { Persons find that the rotating door is impractical } \\
\text { e.g. when carrying large boxes or musical } \\
\text { instruments. }\end{array}$ & 3 & 4.41 \\
\hline Ignorance & $\begin{array}{l}\text { Persons do not understand the implication of their } \\
\text { door usage behaviour but may change their } \\
\text { behaviour with basic education provision. }\end{array}$ & 8 & 11.76 \\
\hline Phobia & $\begin{array}{l}\text { Persons entering the building suffer from a phobia } \\
\text { (such as confined spaces) and therefore prefer to } \\
\text { avoid using the rotating doors. }\end{array}$ & 2 & 2.94 \\
\hline Total & & 68 & \\
\hline
\end{tabular}

